\title{
Ruokintafrekvenssin vaikutus täysikasvuisten emolehmien tuotantoon
}

\section{b) Työnmenekki ja tuotannon talous}

\author{
Lauri Juntti $^{1)}$, Anna-Maija Heikkilä ${ }^{1)}$ Reetta Palva ${ }^{2)}$, Mika Peltonen ${ }^{2)}$, Veli-Matti Tuure ${ }^{2)}$ ja Merja \\ Manninen $^{3)}$ \\ ${ }^{1)}$ MTT Taloustutkimus, Luutnantintie 13, 00410 Helsinki lauri.juntti@mtt.fi, anna- \\ maija.heikkila@mtt.fi \\ ${ }^{2)}$ Työtehoseura ry, Maatalousosasto, PL 13, 05201 Rajamäki reetta.palva@tts.fi, \\ mika.peltonen@tts.fi,veli-matti.tuure@tts.fi. \\ 3) MTT, 31600 Jokioinen merja.manninen@mtt.fi.
}

\section{Tiivistelmä}

Tämä tutkimus selvitti, voidaanko täysikasvuisten emolehmien ruokintakertoja harventaa pidettäessä eläinten energian saanti samana kuin päivittäisessä ruokinnassa ja voidaanko näin menetellen parantaa tuotannon taloudellista tulosta. Tutkimus jakaantui tuotantotuloksia ja eläinten hyvinvointia sekä työnmenekkiä ja tuotannon taloutta käsitelleisiin osioihin. Tässä osiossa tarkastellaan harvennetun ruokinnan vaikutusta työnmenekkiin ja sitä kautta emolehmätilan taloudelliseen tulokseen.

Emolehmien hoitotöihin kuluvaa aikaa mitattiin ruokintakokeen eri vaiheissa MTT:nn emolehmänavetalla Tohmajärvellä. Pääpaino työaikatutkimuksissa oli sisäruokintakauden töissä, joissa eläinten ruokintaan liittyvät työt eri ruokintafrekvensseillä erosivat toisistaan; osalle eläimistä rehut jaettiin tavalliseen tapaan päivittäin, osalle kolmen päivän rehuannos kerralla joka kolmas päivä. Tulokset perustuvat mahdollisuuksien mukaan usean mittauskerran tietoihin. Työnmenekit määritettiin yksityiskohtaisille työnosille, joiden perusteella laskettiin laajempien kokonaisuuksien työnmenekkejä.

Eri ruokintatapojen taloudellisia vaikutuksia tutkittiin vertaamalla niiden kustannuksia keskenään. Ainoa kustannusero eri menetelmien välillä oli työkustannuksissa, mutta työkustannuksen merkityksen selvittämiseksi laskettiin vertailussa mukaan myös muut tuotantokustannuksen erät.

Tutkimuksen mukaan säilörehun ja kuivan heinän jako joka kolmas päivä vähensi ruokintatyönmenekkiä 35 prosenttia kerran päivässä tapahtuvaan verrattuna. Tohmajärven emolehmänavetan olosuhteissa tämä merkitsi vajaan kolmen tunnin työnmenekin säästöä emoa ja vuotta kohti laskettuna. Joka kolmas päivä tehtävän ruokinnan koko työkustannuksen ja muuttuvien kustannusten summa on kuitenkin vain noin neljä prosenttia alempi kuin vastaava summa kerran päivässä tapahtuvassa ruokinnassa. Koko tuotantokustannusta tarkasteltaessa kustannussäästö on noin kolme prosenttia.

Joka kolmas päivä tapahtuvalla ruokinnalla saavutettava kustannussäästö suhteutettuna koko tuotantokustannukseen ei ole kovin suuri. Suhteutettuna vasikkatuotannossa saavutettavaan verrattain pieneen katteeseen säästöä voidaan kuitenkin pitää merkittävänä. Kustannussäästöä oleellisempaa voi olla harvennetun ruokinnan tarjoama jouston mahdollisuus emolehmätilan töiden järjestämiseen, mikä puolestaan voi edesauttaa viljelijäperhettä parantamaan tilansa taloudellista kokonaistulosta esimerkiksi sivuansioiden avulla.

Asiasanat: emolehmä, ruokinta, työnmenekki, työkustannus, tuotantokustannus 


\section{Johdanto}

Emolehmillä ruokintakertojen vähentämisen tavoitteena on säästää työkustannuksia ja siten parantaa tuotannon taloudellista tulosta. Tämä tutkimus selvitti joka kolmas päivä toteutetun ruokinnan vaikutukset emolehmien tuotantoon ja hyvinvointiin sekä työnmenekin säästön kautta saavutettavaan kustannussäästöön. Koejärjestely sekä tuotantoa ja hyvinvointia koskevat tulokset esitetään kohdassa a) Tuotantotulokset ja eläinten hyvinvointi. Tässä osiossa tarkastellaan ruokintafrekvenssin vaikutusta emolehmätuotannon vaatimaan työpanokseen ja taloudelliseen tulokseen.

Tutkimusta edelsi emolehmänavetalla sisäruokintakaudella 2002-2003 tehty esiselvityskoe, jonka tulosten perusteella ruokinta tässä kokeessa toteutettiin kahdella karkearehulla, heinällä ja säilörehulla. Joka kolmas päivä ruokitut eläimet saivat kolmen päivän rehumäärän kerta-annoksena ja rehuissaan yhtä paljon energiaa kuin joka päivä ruokitut eläimet. Emolehmien hoitotöiden työnmenekki selvitettiin kokeen kuluessa. Pääpaino työaikatutkimuksissa oli sisäruokintakauden töissä, joissa eläinten ruokintaan liittyvät työt erosivat toisistaan ruokintafrekvenssin mukaan.

\section{Aineisto ja menetelmät}

\section{Koejärjestely}

Koe tehtiin MTT:n emolehmänavetalla Tohmajärvellä. Kokeessa oli 32 täysikasvuista kantavaa hereford-emoa. Talven emot olivat kylmäpihaton neljässä karsinassa. Kahden karsinan eläimille rehu jaettiin päivittäin (Käsittely D), toiset kaksi karsinallista eläimiä saivat rehun joka kolmas päivä (Käsittely 3D). Koe alkoi 22.10.2003 ja päättyi vasikoiden vieroitukseen ja emojen tiineystarkastuksiin syyskuussa 2004. Emot poikivat keväällä ajanjaksolla 16.3. - 1.5.2004. Laidunkaudella emot, niiden vasikat ja astutussonni olivat yhdessä ryhmässä.

\section{Työnmenekin tutkimus}

Kokeen aikana mitattiin emolehmien hoitotöihin kuluvaa aikaa. Tulokset perustuvat mahdollisuuksien mukaan usean mittauskerran tietoihin, eli jokaisen työnmenekkiluvun takana on useita mittauksia ko. työsuorituksesta. Työnmenekit määritettiin yksityiskohtaisille työnosille (työnerille tai osavaiheille), joiden perusteella laskettiin laajempien kokonaisuuksien työnmenekkejä. Ajanmittaus suoritettiin tiedonkeruuta ohjaavalla ja palautusmenetelmää soveltavalla elektronisella lomakkeella. Siirtymismatkat ja pinta-alat määritettiin optisen etäisyysmittarin avulla. Rehujen ja kuivikkeiden määrät saatiin tutkimustilalta, joten niitä ei määritetty työntutkimuksen yhteydessä. Työhön vaikuttavista olosuhteista määritettiin mittausten avulla valaistusvoimakkuutta ja melutaso. Olosuhdemittaukset suoritettiin ajanmittausten yhteydessä. Navetan lämpöolot saatiin tutkimustilalta, joten niitä ei määritetty työntutkimusten yhteydessä.

Koska työnmenekkitutkimuksen ensisijaisena tavoitteena oli selvittää ruokintafrekfenssin vaikutus työnmenekkiin, pääpaino työaikamittauksissa oli sisäruokintakauden ruokintatöiden mittaamisessa. Emolehmänavetalle tehtiin sisäruokintakaudella kolme tutkimuskäyntiä ajalla 20.1.-11.2.2004. Tutkimuspäiviä kertyi 11. Laidunkaudella tehtiin yksi kaksipäiväinen tutkimuskäynti 30.8-1.9.2004. Kooste tehdyistä mittauksista (kerranteet) on esitetty Taulukossa 1. Poikima-ajan (8.3 - 13.5.2004) työmäärää selvitettiin koenavetan henkilökunnan pitämän kirjanpidon avulla. Ajankäyttötieto kerättiin mittausten asemesta kirjanpidon avulla, sillä säännöllisistä tarkastuksista poikkeavien töiden ajoitus ei ollut tarkasti ennakoitavissa. Yhdessä laadittuun kirjanpitolomakkeeseen kirjattiin tarkistuskäyntien ajankohdat, mahdollisiin toimenpiteisiin kulunut työaika, toimenpiteeseen osallistuneiden henkilöiden lukumäärä sekä tieto, mihin karsinaan toimenpide kohdistui. Kokonaistyönmenekin selvittämiseksi mittausaineistoa täydennettiin harvoin toistuvien töiden osalta Työtehoseuran muissa tutkimuksissa tehdyillä työaikamittauksilla (mm. Alakruuvi 1996, Klemola 1992, Orava 1980, Peltonen ja Karttunen 2002). 
Taulukko 1. Emolehmien ruokintakokeessa tehdyt työaikamittaukset, kpl.

\begin{tabular}{lcc}
\hline Kohde & $\begin{array}{c}\text { Ruokinta } \\
\text { päivittäin }\end{array}$ & $\begin{array}{c}\text { Ruokinta joka } \\
\text { kolmas päivä }\end{array}$ \\
\hline Heinäruokinta & 11 & 5 \\
Säilörehuruokinta & 11 & 5 \\
Rehujen kuormaus, heinä & 11 & 3 \\
Rehujen kuormaus, säilörehu & 11 & 3 \\
Rehujen punnitus, heinä & 11 & 3 \\
Rehujen punnitus, säilörehu & 11 & 3 \\
Olkikuivitus, silppuri & 2 & 2 \\
Olkikuivitus, paaliolki & 1 & 2 \\
Turvekuivitus & 1 & 1 \\
Lannanpoisto lantakäytävältä & 3 & 3 \\
Eläinten punnitus & 3 & 1 \\
Eläinten siirto laidunlohkolla (samassa ryhmässä) & 1 & 2 \\
Tarkastuskäynti laitumella & 2 & 3 \\
\hline
\end{tabular}

\section{Tutkimusnavetan työmenetelmät}

Tohmajärven emolehmänavetta on kylmäpihatto, jossa eläimet ovat karsinoissa. Rehuvarastot sijaitsevat pihaton välittömässä yhteydessä. Säilörehu varastoitiin laakasiilossa, josta rehu irrotettiin pienkuormaimella. Siilosta ruokintapöydälle rehu siirrettiin rehuvaunuilla, joista rehu jaettiin eläinten eteen talikolla. Vaunut täytettiin joko talikolla tai pienkuormaimella. Rehujen punnitusta varten vaunut siirrettiin vaa'alle, josta punnituksen jälkeen edelleen ruokintapöydälle. Rehujen punnitukseen käytetty aika on koetoimintaa, minkä vuoksi se tässä yhteydessä erotettiin varsinaisesta työajasta. Heinä oli varastoitu suurpaaleihin, jotka hajotettiin pienkuormainta käyttäen. Muutoin heinäruokinta toteutettiin samoin menetelmin kuin säilörehuruokinta.

Kauas eläinten ulottuvilta siirtyneitä rehuja siirrettiin lähemmäksi ja tasattiin ruokintapöydällä ruokintakertojen välillä. Säilörehun tasoittelu tapahtui käsittelyllä D yhden kerran ruokintapäivänä ja käsittelyllä 3D kolme kertaa ruokintapäivänä. Kuivaa heinää tasoiteltiin käsittelyllä D kaksi kertaa ruokintapäivänä ja käsittelyllä 3D neljä kertaa. Käsittelyllä 3D kolme tasoittelua tapahtui samana päivänä kuin ruokinta, mutta neljäs tasoittelu siirtyi seuraavaan aamuun, varsinkin suurissa heinäannoksissa. Tavallisesti ruokintapöytää ei tarvinnut puhdistaa, vaan eläimet söivät tarkasti kaikki rehutähteet. Lannanpoiston ajaksi emot ajettiin ulkokarsinoihin. Lanta tyhjennettiin lantakäytävältä traktorin etukuormaimella.

Olkikuivitus tehtiin lannanpoiston jälkeen 2 - 3 kertaa viikossa, tarpeen mukaan. Työ tehtiin kahden henkilön työryhmässä. Neljään karsinaan jaettiin kerralla yhteensä keskimäärin neljä olkipaalia. Turvekuivitus tehtiin yleensä joka toinen viikko, lannanpoiston jälkeen kuten olkikuivituskin. Turve kuljetettiin pienkuormaimen kauhassa turvevarastolta kuivikepohjille.

Eläinten punnitus koenavetalla liittyi tutkimustoimintaan. Koska eläimiä punnitaan myös käytännön emolehmätiloilla, punnitustyö laskettiin mukaan kokonaistyönmenekkiin. Työ tehtiin karsina kerrallaan siten, että koko ryhmä siirrettiin ensin punnituskarsinaan, josta ne otettiin yksitellen vaa'alle. Vaa'an läpi kuljettuaan eläimet pääsivät toiseen karsinaan, josta edelleen takaisin omaansa. Punnituksen yhteydessä emoille tehtiin kuntoluokitus. Jos samalla kerralla punnittiin useita emoryhmiä, punnitut eläimet siirrettiin ja suljettiin ulkotarhaan.

Poikimiskaudella emojen poikimista seurattiin ympärivuorokautisilla tarkastuskäynneillä, joita tehtiin 2 - 3 tunnin välein. Käynneillä tarkastettiin yleistilanne ja seurattiin mahdollista käynnissä olevaa poikimista. Tarpeen vaatiessa avustettiin poikimisessa ja vasikan imemään saamisessa.

Laidunkaudella kaikki emot vasikoineen sekä astutussonni olivat yhdessä ryhmässä samalla laitumella. Laitumella tehtiin tarkastus pääsääntöisesti kaksi kertaa päivässä, aamuin illoin. Alkukesällä tarkastuksen yhteydessä seurattiin kiimojen esiintymistä ja kirjattiin astumishavainnot, mikä lisäsi tarkastukseen kulunutta aikaa. Eläimet eivät saaneet lisärehuja. Kivennäisrehua vietiin laitumelle tarpeen mukaan, yleensä kerran viikossa. Laidunala oli jaettu kahdeksaan lohkoon, joista alkukesästä käytössä oli kuusi lohkoa. Eläimet siirrettiin yleensä vierekkäiseltä lohkolta seuraavalle, joten siirtomatka oli pääsääntöisesti lyhyt. Viimeiseltä lohkolta jälleen ensimmäiselle lohkolle siirryttäessä muodostui pitempi matka. Eläinten siirron jälkeen siirrettiin vesiastia, vesijohdot ja kivennäisastia. Lai- 
dunaidat oli tehty valmiiksi ennen laidunkautta. Koko lohkoa ympäröivä aita on pysyvää aitaa, mutta osalohkoja erottavat aidat rakennetaan ja puretaan vuosittain. Lohkot 1-6 puhdistusniitettiin kerran kesän aikana. Samoin aidanaluset niitettiin kerran kesässä.

\section{Taloustutkimus}

Ruokintafrekvenssi ei vaikuttanut eläinten tuotantotuloksiin eikä rehunkulutukseen, joten ainoa taloudellisesti merkittävä ero menetelmien välillä oli työnmenekissä. Tutkimuksessa määritettyjen työnmenekkien ja maatalouden kannattavuuskirjanpidossa käytettävän viljelijäperheen palkkavaatimuksen avulla laskettiin emolehmätuotannon työkustannus eri ruokintafrekvensseillä. Työkustannuksen säästön merkityksen selvittämiseksi tutkimuksessa määritettiin lisäksi emolehmätuotannon koko tuotantokustannus emoa ja vuotta kohden. Rehukustannus laskettiin kokeessa todetun rehunkulutuksen ja rehujen markkinahintojen tai tuotantokustannusten perusteella. Tuotantokustannuksen muiden kustannuserien, kuten kone-, rakennus- ja yleiskustannuksen, määrittämisessä käytettiin kannattavuuskirjanpidossa mukana olevilta emolehmätiloilta kerättyjä tietoja sekä maa- ja metsätalousministeriön rakentamisen ohjekustannuksia.

\section{Tulokset}

\section{Työnmenekki}

Taulukossa 2 esitetään vuotuinen työnmenekki emolehmää kohden jaoteltuna eri töiden osalle. Tutkimuksen kannalta oleellisen heinä- ja säilörehuruokinnan työnmenekki kuvataan työvaiheittain Liitteessä 1 . Säilörehuruokinnassa emolehmien ruokinta kolmen päivän välein vähensi työnmenekkiä 37 \% ja heinäruokinnassa 33 \% verrattaessa ruokintaan kerran päivässä. Kaikkiaan säästö ruokintatyössä oli 35 \%. Koenavetan olosuhteissa se merkitsi vajaan kolmen tunnin työnsäästöä emoa ja vuotta kohden. Kun kokonaistyönmenekki oli joka päivä ruokituilla emoilla vajaat 16 tuntia/vuosi, saavutettu työnsäästö merkitsi noin 17 prosentin työnsäästöä vuotuisessa työnmenekissä. Karjan koko ratkaisee, onko säästön määrällä käytännön merkitystä emolehmätilalle.

Sisäruokintakauden töitä ruokinnan lisäksi olivat lannanpoisto lantakäytävän alueelta, olki- ja turvekuivitus sekä eläinten punnitus. Laidunkauden työnmenekkiin vaikuttaa ratkaisevasti laidunten sijainti. Tässä tapauksessa siirtomatkat olivat lyhyitä (Taulukko 2).

Taulukko 2. Emolehmätuotannon kokonaistyönmenekki eri ruokintafrekvensseillä.

\begin{tabular}{lcc}
\hline Työnmenekki h/emo/vuosi & Ruokinta päivittäin & Ruokinta joka kolmas päivä \\
\hline & & \\
Ruokinta (sisäruokinta) & 7,85 & 5,08 \\
Lannanpoisto, kuivitus, ym. sisäruokintakauden & 2,75 & 2,75 \\
työt & & 2,10 \\
Poikimisen seuranta & 2,10 & 2,97 \\
Laidunkauden työt & 2,97 & 12,90 \\
\hline Yhteensä & 15,67 & \\
\hline
\end{tabular}

Tohmajärven emolehmänavetalla käytetyt työmenetelmät eivät kaikilta osin vastanneet yleisesti emolehmätiloilla käytettäviä työmenetelmiä, ja sen vuoksi mittaustulosten yleistämiseen tulee suhtautua varauksella. Koetoiminnan vaikutusta työaikaan ei myöskään pystytty täysin poistamaan. Esimerkiksi ryhmäkohtaisista rehumääristä johtuen rehujen siirtoon käytettyjen rehuvaunujen täyttöaste ei välttämättä ollut aina suurimmillaan. Erilaiset käytännöt esimerkiksi poikimisten valvonnassa voivat myös aiheuttaa suurta vaihtelua tilakohtaiseen työnmenekkiin. Siten harvennetulla ruokinnalla saavutettava työnsäästö on tarkkaa tietoa haluttaessa katsottava aina tilakohtaisten olosuhteiden mukaan ja suhteutettava kyseisen tilan kokonaistyönmenekkiin.

\section{Taloudelliset tulokset}

Tutkimuksessa määritettyjen työnmenekkien perusteella emolehmien ruokinta joka kolmas päivä alensi kokonaistyökustannusta noin 19 \% joka päivä tapahtuvaan ruokintaan verrattuna. Saavutetulla säästöllä ei kuitenkaan ole kovin suurta vaikutusta emolehmätilan taloudelliseen kokonaistulokseen, 
Kuva 1. Emolehmätuotannon kustannusrakenne eri ruokintafrekvensseillä.

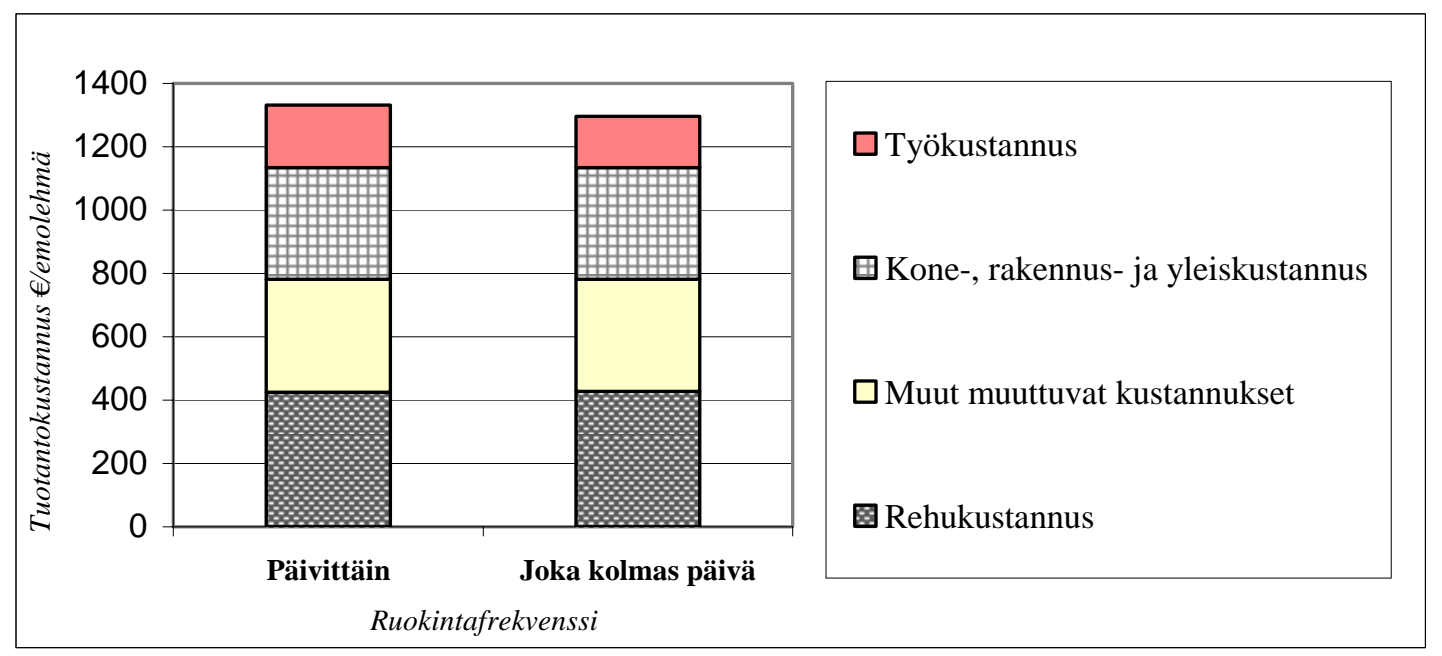

koska työkustannuksen osuus kokonaiskustannuksista kerran päivässä tapahtuvalla ruokinnalla on noin $15 \%$ ja joka kolmas päivä ruokittaessa noin $12 \%$. Suurin yksittäinen kustannuserä molemmilla ruokintafrekvensseillä on rehukustannus, jonka osuus kokonaiskustannuksista on yli $30 \%$. Suuri kustannusvaikutus on myös muilla muuttuvilla kustannuksilla, joiden osuus kokonaiskustannuksista on molemmilla ryhmillä yli 25 \%. Myös yleis-, kone-, rakennuskustannusten osuus kokonaiskustannuksesta on suurempi kuin työkustannuksen.

Kuvassa 1 on esitetty emolehmätuotannon kustannusrakenne eri ruokintafrekvensseillä. Kuviosta ilmenee, kuinka harvennetulla ruokinnalla saavutettu kustannussäästö on pieni, kun sitä verrataan koko tuotantokustannukseen. Joka kolmas päivä tehtävän ruokinnan koko työkustannuksen ja muuttuvien kustannusten summa on vain noin neljä prosenttia alempi kuin vastaava summa kerran päivässä tapahtuvassa ruokinnassa. Koko tuotantokustannusta tarkasteltaessa kustannussäästö on noin kolme prosenttia.

\section{Johtopäätökset}

Tutkimuksen mukaan säilörehun ja kuivan heinän jako joka kolmas päivä vähensi ruokintatyönmenekkiä 35 prosenttia kerran päivässä tapahtuvaan verrattuna. Joka kolmas päivä tapahtuvalla ruokinnalla saavutettava kustannussäästö suhteutettuna kaikkiin tuotantokustannuksiin ei ole kovin suuri. Tähän on syynä se, että työkustannuksen osuus emolehmätilan kokonaiskustannuksista on pieni verrattuna esimerkiksi rehukustannukseen. Vasikkatuotannossa saavutettaviin verrattain pieniin katteisiin suhteutettuna säästöä voidaan kuitenkin pitää merkittävänä. Viime vaiheessa työnsäästön merkitys riippuu karjan koosta, sillä isossa yksikössä pienilläkin eläinkohtaisilla säästöillä voidaan saada aikaan merkittävä kokonaisvaikutus. Kokeessa todettu harvennetun ruokinnan soveltuminen emolehmille voi kustannussäätöjen ohella tarjota muita hyötyjä, kuten jouston mahdollisuuden emolehmätuotannon töiden ja työvoiman järjestämiseen. Tällaiset tekijät voivat luoda tilalle mahdollisuuksia päästä hyvään taloudelliseen kokonaistulokseen esimerkiksi sivuansioiden avulla.

\section{Kirjallisuus}

Alakruuvi, A. 1996. Maatalouden työnormit: lypsykarjan hoitotyöt. Työtehoseuran maataloustiedote 10 (476): 1 -12 .

Klemola, E. 1992. Lihanautojen hoidon työmenetelmät ja -menekit. Työtehoseuran maataloustiedote 11 (418): $1-12$.

Orava, R. 1980. Maataloustöiden standardiaikajärjestelmä. Työtehoseuran maatalous- ja rakennusosaston moniste 1.

Peltonen, M. \& Karttunen, J. 2002. Lypsyn ja puhtaanapitotöiden työnmenekki pihatossa -työmenetelmät ja toiminnallisuus. Työtehoseuran maataloustiedote 10 (550): 1 - 12. 


\section{Liite 1(1)}

\section{Säilörehuruokinnan työnmenekit eri ruokintafrekfensseillä}

\begin{tabular}{|c|c|c|c|c|c|c|c|c|}
\hline \multirow[t]{2}{*}{ SÄILÖREHURUOKINTA } & \multicolumn{4}{|c|}{ ruokinta päivittäin } & \multicolumn{4}{|c|}{ ruokinta joka kolmas päivä } \\
\hline & $\mathrm{min} / \mathrm{krt}$ & $\min / 100 \mathrm{~kg}$ & $\mathrm{~min} / 10 \mathrm{~m}$ & $\min / 3 p v(*$ & $\mathrm{min} / \mathrm{krt}$ & $\mathrm{min} / 100 \mathrm{~kg}$ & $\mathrm{~min} / 10 \mathrm{~m}$ & $\min / 3 p v\left(^{*}\right.$ \\
\hline \multicolumn{9}{|c|}{ Säilörehun kuormaus ja punnitus } \\
\hline Aloittelu & 1,15 & & & 3,45 & 1,30 & & & 1,30 \\
\hline Irrotus bobcatilla kasasta & 3,72 & 2,80 & & & & & & \\
\hline Kuormaus käsin talikolla & 6,13 & 3,05 & & & & & & \\
\hline Kuormaus bobcatilla kärryyn & 3,59 & 1,58 & & 10,83 & 8,98 & 1,35 & & 9,25 \\
\hline Siirto punnitukseen & 0,76 & & 0,38 & 2,28 & 0,58 & & 0,29 & 0,58 \\
\hline Punnitus & 4,82 & 4,28 & & & & & & \\
\hline Lopettelu & 0,13 & & & 0,39 & & & & 0,13 \\
\hline Punnituspaikan siivous & 3,68 & & & & & & & \\
\hline Säilörehuvaraston siivous & 1,66 & & & 3,77 & 0,85 & & & 1,26 \\
\hline Kuormaus yhteensä & & & & 20,72 & & & & 12,52 \\
\hline \multicolumn{9}{|l|}{ Säilörehun jako } \\
\hline Aloittelu & 0,96 & & & 2,88 & 1,04 & & & 1,04 \\
\hline Siirto ruokintapöydälle & 1,40 & & 0,55 & 5,35 & 1,97 & & 0,50 & 1,62 \\
\hline Jako $1 / 2$ & 1,64 & & 1,53 & 10,05 & 3,45 & 1,00 & & 7,39 \\
\hline Jako 3/4 & 1,53 & 1,40 & & 3,68 & 1,15 & & & \\
\hline Kärryjen siirto pois, lopettelu & 1,12 & & 0,44 & 4,28 & 1,90 & & 0,48 & 1,56 \\
\hline Lopettelu & 0,75 & & & & 0,75 & & & \\
\hline Ruokintapöydän puhdistus & 1,53 & & & 4,59 & 1,53 & & & 1,53 \\
\hline Jako yhteensä & & & & 27,15 & & & & 13,15 \\
\hline \multicolumn{9}{|l|}{ 1. Säilörehun tasoittelu } \\
\hline Aloittelu & 0,20 & & & 0,61 & 0,32 & & & 0,32 \\
\hline Tasoittelu 1/2 & 0,37 & 5,58 & & 2,84 & 1,08 & 0,52 & & 2,03 \\
\hline Tasoittelu 3/4 & 0,57 & 8,57 & & & 0,95 & 0,51 & & \\
\hline Tasoittelu $1 \& 3 / 2 \& 4$ & 0,80 & 4,59 & & & & & & \\
\hline Lopettelu & 0,31 & & & 0,92 & 0,68 & & & 0,68 \\
\hline \multicolumn{9}{|l|}{ 2. Säilörehun tasoittelu } \\
\hline Aloittelu & & & & & 0,36 & & & 0,36 \\
\hline Tasoittelu 2 & & & & & 0,57 & 0,81 & & 1,22 \\
\hline Tasoittelu 4 & & & & & 0,65 & 0,94 & & \\
\hline Tasoittelu 2\&4 & & & & & 1,75 & 1,98 & & \\
\hline Lopettelu & & & & & 0,43 & & & 0,43 \\
\hline \multicolumn{9}{|l|}{ 3. Säilörehun tasoittelu } \\
\hline Aloittelu & & & & & 0,12 & & & 0,12 \\
\hline Tasoittelu 2 & & & & & 0,67 & 0,74 & & 1,93 \\
\hline Tasoittelu 4 & & & & & 1,26 & 1,39 & & \\
\hline Tasoittelu 2\&4 & & & & & 0,87 & & & \\
\hline Lopettelu & & & & & 0,09 & & & 0,09 \\
\hline Tasoittelut yhteensä & & & & 4,38 & & & & 7,18 \\
\hline Säilörehuruokinta yhteensä & & & & 52,25 & & & & 32,85 \\
\hline
\end{tabular}




\section{Liite 1(2)}

\section{Heinäruokinnan työnmenekit eri ruokintafrekfensseillä}

\begin{tabular}{|c|c|c|c|c|c|c|c|c|}
\hline \multirow{2}{*}{ HEINÄRUOKINTA } & \multirow[b]{2}{*}{$\mathrm{min} / \mathrm{krt}$} & \multicolumn{2}{|c|}{ ruokinta päivittäin } & \multirow[b]{2}{*}{$\min / 3 p v(*$} & \multirow[b]{2}{*}{$\min / \mathrm{krt}$} & \multicolumn{3}{|c|}{ ruokinta joka kolmas päivä } \\
\hline & & $\min / 100 \mathrm{~kg}$ & $\mathrm{~min} / 10 \mathrm{~m}$ & & & $\mathrm{~min} / 100 \mathrm{~kg}$ & $\mathrm{~min} / 10 \mathrm{~m}$ & $\min / 3 p v(*$ \\
\hline \multicolumn{9}{|l|}{ Heinän kuormaus ja punnitus } \\
\hline Aloittelu & 0,83 & & & 2,50 & 1,41 & & & 1,41 \\
\hline Kuormaus käsin talikolla & 3,39 & 4,84 & & & & & & \\
\hline paalin hajoitus bobcatilla & 1,65 & 2,36 & & & & & & \\
\hline Kuormaus bobcatilla kärryyn & 2,74 & 3,15 & & 8,49 & 6,15 & 2,35 & & 6,40 \\
\hline Siirto punnituks een & 0,81 & & 0,27 & 2,42 & 1,52 & & 0,51 & 1,52 \\
\hline Punnitus & 3,97 & & & & 4,58 & & & \\
\hline Siirto ruokintapöydälle & 1,37 & & 0,54 & 5,24 & 3,09 & & 0,78 & 2,54 \\
\hline Lopettelu & 0,55 & & & 1,65 & 0,38 & & & 0,38 \\
\hline Uuden paalin otto kasasta & 2,38 & 0,63 & & 1,69 & 0,76 & 0,63 & & 1,70 \\
\hline Narujen poisto paalista & 2,70 & 1,01 & & 2,71 & 2,33 & 1,01 & & 2,73 \\
\hline Punnituspaikan siivous & 4,34 & & & & 4,24 & & & \\
\hline Rehuvaraston siivous & & & & 4,09 & 4,09 & & & 4,09 \\
\hline Kuormaus yhteensä & & & 28,79 & 28,79 & & & & 20,78 \\
\hline \multicolumn{9}{|l|}{ Heinän jako } \\
\hline Aloittelu & 0,34 & & & 1,01 & 0,50 & & & 0,50 \\
\hline \multicolumn{9}{|l|}{ Siirto ruokintapöydälle } \\
\hline Jako 1/2 & 1,05 & 2,46 & & 6,58 & 1,69 & 1,24 & & 3,24 \\
\hline Jako $3 / 4$ & 1,04 & 2,41 & & & 1,42 & 1,14 & & \\
\hline Kärryjen siirto pois, lopettelu & 0,84 & & 0,33 & 3,21 & 0,86 & & 0,22 & 0,71 \\
\hline Lopettelu & 0,21 & & & & & & & \\
\hline Jako yhteensä & & & 10,80 & 10,80 & & & & 4,45 \\
\hline \multicolumn{9}{|l|}{ 1. Heinän tasoittelu } \\
\hline Aloittelu & 0,18 & & & 0,53 & 0,20 & & & 0,20 \\
\hline Tasoittelu 1/2 & 0,45 & 4,04 & & 3,10 & 0,48 & 0,65 & & 1,30 \\
\hline Tasoittelu 3/4 & 0,58 & 4,96 & & & 0,82 & 1,10 & & \\
\hline Tasoittelu $1 \& 3 / 2 \& 4$ & 1,44 & 12,73 & & & 0,89 & & & \\
\hline Lopettelu & 0,44 & & & 1,32 & 0,36 & & & 0,36 \\
\hline \multicolumn{9}{|l|}{ 2. Heinän tasoittelu } \\
\hline Aloittelu & 0,14 & & & 0,43 & 0,13 & & & 0,13 \\
\hline Tasoittelu 1/2 & 0,25 & 5,36 & & 1,91 & 0,51 & & & 0,96 \\
\hline Tasoittelu 3/4 & 0,39 & 8,13 & & & 0,45 & & & \\
\hline Tasoittelu 2\&4 & 0,55 & & & & 1,28 & 2,29 & & \\
\hline Lopettelu & 0,44 & & & 1,33 & 0,31 & & & 0,31 \\
\hline \multicolumn{9}{|l|}{ 3. Heinän tasoittelu } \\
\hline Aloittelu & & & & & 0,10 & & & 0,10 \\
\hline Tasoittelu 2 & & & & & 0,67 & 1,92 & & 1,06 \\
\hline Tasoittelu 4 & & & & & 0,39 & 1,12 & & \\
\hline Tasoittelu $2 \& 4$ & & & & & 1,36 & 25,66 & & \\
\hline Lopettelu & & & & & 0,55 & & & 0,55 \\
\hline \multicolumn{9}{|l|}{ 4. Heinän tasoittelu } \\
\hline Aloittelu & & & & & 0,18 & & & 0,18 \\
\hline Tasoittelu 2 & & & & & 0,55 & 3,93 & & 1,27 \\
\hline Tasoittelu 4 & & & & & 0,72 & 3,44 & & \\
\hline Tasoittelu 2\&4 & & & & & 0,50 & 23,81 & & \\
\hline Lopettelu & & & & & 0,54 & & & 0,54 \\
\hline Tasoittelut yhteensä & & & 8,62 & 8,62 & & & & 6,94 \\
\hline Heinäruokinta yhteensä & & & & 48,21 & & & & 32,17 \\
\hline
\end{tabular}

